\title{
UMA GRANDE CONQUISTA: REVISTA LATINO-AMERICANA DE ENFERMAGEM INGRESSA NA COLEÇÃO SCIELO
}

Ao iniciarmos o ano de 2002 temos a satisfação de informar aos leitores que a Revista Latino-Americana de Enfermagem passa a integrar a coleção SciELO Brasil.

A SciELO - Scientific Eletronic Library Online é uma biblioteca virtual composta por periódicos científicos brasileiros que atinjam os critérios de inclusão e que tenham sido selecionados no contexto da política e dos procedimentos para admissão e permanência na coleção. A SciELO integra um projeto de parceria entre a FAPESP e a BIREME/OPAS/OMS, que nasceu em 1997 e começou a operar regularmente em 1998, cujo objetivo é o desenvolvimento de uma metodologia comum para a preparação, disseminação e avaliação da produção científica em formato eletrônico. A metodologia criada e aplicada converte para o formato eletrônico edições completas de periódicos científicos, disponibilizando-os para acesso e gerando automaticamente bases de dados referenciais e estatísticos de uso e de citações ${ }^{(1-2)}$.

Atualmente fazem parte da referida biblioteca virtual sessenta e cinco revistas da área de saúde e a Revista Latino-Americana de Enfermagem, a partir de agora identificada pela sigla RLAE, é a única da Enfermagem. Assim, pertencer ao elenco de títulos da SciELO representa uma grande conquista para todos os enfermeiros.

A elegibilidade da RLAE e a decisão final do Comitê Consultivo da SciELO Brasil dependeu de uma tramitação do processo e da confirmação dos critérios SciELO para admissão de periódicos na coleção. Dentre esses critérios, destaca-se o da indexação em índices internacionais. Como se sabe, a indexação de uma revista em uma base de dados possibilita além de maior visibilidade do conhecimento produzido, sua disseminação nacional e/ou internacional e o controle bibliográfico da produção científica através do registro, acesso e preservação da memória. Os critérios de seleção para indexação em uma base de dados estão voltados aos objetivos, áreas temáticas e de interesse. A qualidade científica dos artigos publicados, composição do corpo editorial, regularidade de publicação, normalização segundo padrões internacionais de editoração e o idioma são os elementos geralmente avaliados pelos comitês de seleção das bases de dados. Norteados pela análise de tais elementos, ajustes na linha editorial foram feitos, o que possibilitou a indexação deste periódico em cinco bases de dados.

Se a participação da RLAE em bases de dados contribui sobremaneira para sua visibilidade, integrar uma biblioteca virtual do porte e do conceito da SciELO representa um ganho considerável em termos de acessibilidade, de significativa expansão da visibilidade e da própria credibilidade do periódico científico e das publicações nele contidas.

Especialmente em termos de acessibilidade, ganha a enfermagem dos países da América Latina e do Caribe e de todos os países de língua portuguesa. Enfim, ganham os enfermeiros brasileiros: - tenham eles como foco de ação a investigação científica, ou a aplicação de resultados de pesquisas à prática clínica nos distintos espaços de trabalho, desde as mais centrais até as mais longínquas localidades do Brasil.

Inicialmente a SciELO disponibilizará os três últimos números da RLAE, ou seja: setembro-outubro/2001; novembro-dezembro/2001 e janeiro-fevereiro/2002. Em etapa subseqüente, toda a coleção será incorporada e disponibilizada a partir de 1997 - ano de criação do projeto SCIELO.

Esta conquista da Enfermagem será tanto mais expressiva, quanto maiores forem os índices de inclusão de periódicos da área nesta coleção, de modo a aumentar a acessibilidade do conhecimento produzido pela Enfermagem brasileira.

Agradecemos a contribuição de todos aqueles que direta e/ou indiretamente nos auxiliaram para essa conquista e informamos que

Editores da Revista Latino-Americana de Enfermagem da Escola de Enfermagem de Ribeirão Preto da Universidade de São Paulo, Centro Colaborador da OMS para o desenvolvimento da pesquisa em enfermagem: ${ }^{1}$ Professor Livre-Docente, e-mail: marziale@eerp.usp.br; ${ }^{2}$ Professor Titular, e-mail: iamendes@eerp.usp.br 
esforços continuarão a ser direcionados para oferecer a nossos leitores um produto de qualidade e aos autores um veículo digno de divulgar seus artigos científicos. Os editores desta revista empenharão, portanto, seus melhores esforços, assim como a Comissão de Editoração, para o fiel cumprimento dos critérios de avaliação de desempenho para permanência na SciELO. Temos a certeza de que a comunidade científica, de igual modo, responderá positivamente a este estímulo, seja através de sua participação como autores, ou como participantes do processo de arbitragem.

\section{REFERÊNCIAS BIBLIOGRÁFICAS}

1. SciELO Brasil. As publicações científicas brasileiras estão ao alcance de suas mãos. Não importa em que parte do mundo você esteja. Pesquisa FAPESP, 2001 jan./fev:9.

2. SciELO Brasil: [citado em 2002 jan 10]; Disponivel em URL: http://www.scielo.br. 


\section{A GREAT ACHIEVEMENT: LATIN AMERICAN JOURNAL OF NURSING ENTERS THE SciELO COLLECTION}

Maria Helena Palucci Marziale ${ }^{1}$

Isabel Amélia Costa Mendes²

As 2002 begins, we are pleased to inform our readers that Revista Latino-Americana de Enfermagem now integrates the SciELO Brazil collection.

SciELO - Scientific Electronic Library Online is an online library consisting of Brazilian scientific journals that have met its inclusion criteria and have been selected in the context of its guidelines and procedures for acceptance and permanence in the collection. SciELO integrates a partnership project between FAPESP (São Paulo State Agency for Research Support) and BIREME/PAHO/WHO which was initiated in 1997 and began to operate regularly in 1998. Its purpose is to develop a common methodology for the preparation, dissemination and evaluation of scientific production in electronic format. The methodology that has been created and applied converts complete editions of scientific journals to electronic format and makes them available for access, thus automatically generating referential databases as well as statistical databases concerning use and citations ${ }^{(1-2)}$.

At present, sixty-five journals in the health field comprise this online library and Revista Latino-Americana de Enfermagem, henceforth identified as RLAE, is the only Nursing journal. Therefore, belonging to the list of titles of SciELO represents a great achievement for all nurses.

The eligibility of RLAE and the final decision of the Consulting Committee of SciELO Brazil depended on the conduct of the procedure and confirmation of the SciELO criterion for acceptance of journals in the collection. Among these criteria, that concerning the indexation in international indexes is emphasized. It is known that indexation in a database enables greater visibility of produced knowledge, its national and/ or international dissemination as well as the bibliographic control of scientific production through recording, access and memory preservation. The criteria used in the selection for indexation in a database are related to its objectives, thematic and interest areas. The scientific quality of the published articles, the composition of the editorial board, publication regularity, guidelines in accordance with international publishing standards and language are the elements that are usually evaluated by databases selection committees. Based on the analysis of such elements, adjustments were made in our editorial line, which enabled the indexation of our journal in five databases.

If the participation of RLAE in databases contributes a great deal to its visibility, integrating an online library as important as SciELO represents a considerable gain in terms of accessibility, significant expansion of visibility as well as credibility of the sicentific journal and its publications.

Particularly in terms of accessibility, Nursing in Latin America, the Caribbean and Portuguese-speaking countries will be benefited. Finally, Brazilian nurses - whether those who focus their action on scientific investigation or who apply research results to clinical practice in distinct workplaces from the most central to the farthest locations in Brazil - will also be benefited.

At first, SciELO will make available the latest three issues of RLAE, that is, September-October/2001; November-December/2001 and January-February/2002. In a subsequent phase, the whole collection will be incorporated and the publications from 1997 on will be made available, since that is the year when the SciELO project was created.

This Nursing achievement will become even more expressive as the inclusion rates of journals in this field increase in SciELO so as to improve accessibility to the knowledge produced by Brazilian Nursing.

We thank all those who have directly or indirectly contributed to this achievement and inform that we will continue dedicating our efforts to offering our readers a quality product as well as to offering authors a vehicle that can honor the dissemination of their scientific articles. The editors of this journal as well as its Publishing Committee will, therefore, make their best endeavors towards the loyal fulfillment of the

Editors of Latin American Journal of Nursing of Ribeirão Preto of the University of São Paulo at Ribeirão Preto College of Nursing - WHO Collaborating Centre for Nursing Research Development: ${ }^{1}$ Associate Professor, e-mail: marziale@eerp.usp.br; ${ }^{2}$ Full Professor, e-mail: iamendes@eerp.usp.br 
performance evaluation criteria for its permanence in SciELO. We are sure that the scientific community will also respond positively to this stimulus by participating as either authors or reviewers.

\section{REFERENCES}

1. SciELO Brasil. As publicações científicas brasileiras estão ao alcance de suas mãos. Não importa em que parte do mundo você esteja. Pesquisa FAPESP, 2001 jan./fev:9.

2. SciELO Brasil: [citado em 2002 jan 10]; Disponível em URL: http://www.scielo.br. 


\section{UNA GRAN CONQUISTA: LA REVISTA LATINOAMERICANA DE ENFERMERÍA INGRESA EN LA COLECCIÓN SCIELO}

Maria Helena Palucci Marziale ${ }^{1}$

Isabel Amelia Costa Mendes²

Al iniciar el año del 2002 tenemos la satisfacción de informar a los lectores que la Revista Latinoamericana de Enfermería pasa a integrar la colección SciELO Brasil.

La SciELO - Scientific Electronic Library Online es una biblioteca virtual compuesta por revistas científicas brasileñas que alcanzan los criterios de inclusión y que han sido seleccionadas en el contexto de la política y de los procedimientos para admision y permanencia en la colección. La SciELO integra un proyecto de colaboración entre FAPESP y BIREME/OPS.OMS, que nació en 1997 y comenzó a operar regularmente en 1998, cuyo objetivo es el desarrollo de una metodología común para la preparación, diseminación y evaluación de la producción científica en formato electrónico. La metodología creada y aplicada convierte para el formato electrónico ediciones completas de revistas científicas, haciéndolas disponibles para el acceso y generando automáticamente bases de datos referenciales y estadísticas de uso y de citaciones $^{(1-2)}$

Actualmente hacen parte de la referida biblioteca virtual sesenta y cinco (65) revistas del área de la salud y la Revista Latinoamericana de Enfermería, a partir de ahora identificada por la sigla RLAE, es la única de enfermería. Así, pertenecer al elenco de títulos de la SciELO representa una gran conquista para todos los enfermeros.

La elegibilidad de la RLAE y la decisión final del Comité Consultivo de la SciELO Brasil, dependió de un tramite del proceso y de la confirmación de los criterios SciELO para la admisión de revistas en la colección. Dentro de esos criterios, se destaca el de la indexación en índices internacionales. Como se sabe, la indexación de una revista en una base de datos hace posible, además de mayor visibilidad del conocimiento producido, su difusión nacional y/o internacional y el control bibliográfico de la producción científica a través del registro, acceso y preservación de la memoria. Los criterios para selección e indexación en una base de datos están orientados a los objetivos, áreas temáticas y de interés. La calidad científica de los artículos publicados, composición del cuerpo editorial, regularidad de la publicación, normatividad según los estándares internacionales de editoriación y el idioma, son los elementos generalmente evaluados por los comités de selección de las bases de datos. Orientados por el análisis de tales elementos, se hicieron ajustes en la línea editorial, lo cual hizo posible la indexación de ésta revista en cinco bases de datos.

Si la participación de la RLAE en bases de datos contribuyó sobremanera para su visibilidad, integrar una biblioteca virtual del porte y del concepto de la SciELO representa un logro considerable en términos de accesibilidad, de significativa expansión de la visibilidad y de la propia credibilidad de la revista científica y de las publicaciones en ella contenidas.

Especialmente en términos de accesibilidad, gana la enfermería de los países de la América Latina y del Caribe y de todos los países de lengua portuguesa. En fin, ganan los enfermeros brasileños: - tengan ellos como centro de acción la investigación científica, o la aplicación de resultados de investigaciones a la práctica clínica de los distintos espacios de trabajo -, desde las más centrales hasta las más lejanas localidades del Brasil.

Inicialmente la SciELO colocará a disposición los tres últimos números de la RLAE, es decir: Septiembre-Octubre/2001; NoviembreDiciembre/2001 y Enero/Febrero/2002. En una etapa posterior, toda la colección será incorporada y colocada a disposición a partir de 1997 año de creación del proyecto SciELO.

Editores de la Revista Latinoamericana de Enfermería de la Escuela de Enfermería de Ribeirão Preto de la Universidad de São Paulo, Centro Colaborador de la OMS para el desarrollo de la investigación en enfermería: ${ }^{1}$ Profesor Libre-Docente, correo electrónico: marziale@eerp.usp.br; ${ }^{2}$ Profesor Titular, correo electrónico: iamendes@eerp.usp.br 
Ésta conquista de la enfermería será más expresiva en la medida en que sean mayores los índices de inclusión de revistas del área en ésta colección, de manera a aumentar la accesibilidad al conocimiento producido por la enfermería brasileña.

Agradecemos la contribución de todos aquellos que directa o indirectamente nos ayudaron para ésta conquista e informamos que los esfuerzos continuaran siendo orientados para ofrecer a nuestros lectores un producto de calidad y a los autores un vehículo digno de divulgar sus artículos científicos. Los editores de ésta revista realizaran sus mejores esfuerzos, así como el comité editorial, para el fiel cumplimiento de los criterios de evaluación del desempeño para la permanencia en la SciELO. Tenemos la seguridad de que la comunidad científica, de igual modo, responderá positivamente a éste estimulo, sea a través de su participación como autores, o como participantes del proceso de arbitraje.

\section{REFERENCIAS BIBLIOGRÁFICAS}

1. SciELO Brasil. As publicações científicas brasileiras estão ao alcance de suas mãos. Não importa em que parte do mundo você esteja. Pesquisa FAPESP, 2001 jan./fev:9.

2. SciELO Brasil: [citado em 2002 jan 10]; Disponível em URL: http://www.scielo.br. 